\title{
Performing Citizenship: Gathering (in the) Movement
}

\section{The Choreographic Format of Circle Dancing and the Round Dance as a Matrix of Collective Action in the Context of Political Assemblies, Protests and Occupations}

\author{
Liz Rech
}

\section{INTRODUCTION}

If one speaks in the activist context of 'the movement', the concept of movement with regard to the 'moving body' is always threefold: the political movement; the actual physical, choreographic movement; and the associated inner movement and its personal affections.

The experience of collective and coordinated movement in public space plays an important role on the political field. This applies not only to the

Translated by Daniel Caleb Thompson

\section{Rech $(\bowtie)$}

Graduate Program Performing Citizenship, HafenCity University Hamburg, Hamburg, Germany

(C) The Author(s) 2019

P. Hildebrandt et al. (eds.), Performing Citizenship, Performance Philosophy, https://doi.org/10.1007/978-3-319-97502-3_5 
kinaesthetic and somatic potency of body experience-which has a direct effect on the social movement itself-but also to the efficacy of its reach to potential viewers because, through its movement in public space, the body's 'indexical force' (Butler 2015, p. 9) becomes visible in a very special way and demands recognition. Butler points out that assemblies, irrespective of specific demands, have meaning: 'The gathering signifies in excess of what is said, and that mode of signification is a concerted bodily enactment, a plural form of performativity' (Butler 2015, p. 8). The resulting questions are:

What forms do these corporeal productions assume?

Which choreographic formats are applied in contexts of political assembly?

Why are such applications extant?

This article deals specifically with the choreographic format of Circle Dancing, which regularly arises in the context of political meetings and occupations. What defines this practice of collective movement? What is its political dimension? And lastly, which roles are played by the body and its 'response/ability' in the context of the ethics of political responsibility and mindful practice of movement?

\section{Gathering in the Movement}

The German word Versammlung (a gathering) is related etymologically to the verb sammeln (to gather) and the noun Sammlung (a collection). In the context of this article, Versammlung can be translated to English as either 'gathering' or 'assembly'. Whereas a 'gathering' describes the 'collection' of clearly defined members, an 'assembly' refers to a meeting that takes place for a specific purpose and is open to the addition and departure of (temporary) participants to the meeting. This presumably explains why the term of 'assembly' has become widespread in the context of contemporary activism; it not only describes the temporary, the fleeting and the incomplete, but also addresses a greater heterogeneity within contemporary political collectivity as witnessed in political protests, such as the Gezi Park protests in Istanbul, 2013: '93.6 per cent stated that they had come to Gezi Park as a "simple citizen", whereas only 6.4 per cent of the participants said they were part of an organization or political party'2 (Uluğ and Acar 2015, p. 122). 
The term 'assembly' also refers to a new understanding of the collective: the collective is no longer considered a homogeneous, closed collective but as an open collective with fraying edges. ${ }^{3}$ This leaves more room for heterogeneity and is reflected in formulations for the description of political performance, such as 'acting plurality', 'body alliances' and 'assemblage' (all three from Butler), 'group subject' (Guattari), 'multitude' (Virno) or 'arrangement' (from the French: agencement, Deleuze).

Accordingly, contemporary political formats of assembly must facilitate space for the integration of diverse positions and heterogeneous bodies. It is not surprising that, in this context, the concept of choreography appears because choreographic formats can assemble heterogeneous bodies in a very specific way through dance-like movement. Kunst highlights the ability of choreographic formats to create temporary communities:

Instead of staging the communities, choreography creates communities through the process of becoming a multifaceted and conflicting mobilization of the body and aesthetic experiences, thus challenging our democratic and political practice. (Kunst 2014, p. 18, translation by author)

In addition to the assembly of heterogeneous bodies, there is another aspect which is significant in the relationship between politics and choreography: (public) space.

In a fundamental way, the relationship between politics and choreography is often determined by the distribution of bodies in space: 'Thinking politics $(. .$.$) is therefore by definition linked to the idea of choreography$ in the truest sense of the word: The art of choreography consists of distributing bodies and their relations in space' (Hölscher and Siegmund 2013, p. 12). Kunst and Hölscher/Siegmund present a line of reasoning used herein-one that presumes a political dimension is to be found in the choreographic arrangement of bodies. The body is seen as an actor that participates in the production of social reality.

The concept of social choreography describes this expanded concept of choreography and transfers it to social and societal spaces. The term social choreography describes a practice that constructively creates a performative order of the social field (as an order of spatial conditions, architecture, body, movement, subjects, collective bodies, objects, materials etc.). Social choreography, as a performative concept, aims at establishing a link between the social and the aesthetic; the aesthetic is assigned a central role in the description of the political, as well as the social (Hewitt 2005, p. 3). It is 
therefore a question of the constitution of social orders which are always determined (through situational) social practices.

The utopian moment of newly materializing 'social figurations' (Elias 1978) in public space is relevant to the way in which citizenship is 'performed' because, in this case, it is about the presence and movement of resisting bodies within the context of social movements. This expanded understanding of choreography has been conceptually extended by many authors writing about resistive choreographic practices, such as Milohnic (2013), ${ }^{4}$ and also Klein $(2013) .{ }^{5}$

This concept will be useful for the analysis of Circle Dancing, since it enables its choreographic structure to be interpreted as a social order and uncovers the degrees to which sociability is inherently present.

The question now is how to evaluate (temporarily generated) communities when they are not merely constituted by origin, group membership and association with a political party or other organization. It is a community that is primarily instantiated by the presence of the individual bodies. In Nancy's book Being Singular Plural, he writes of co-existence as a simultaneity of the differences and 'co-presences' of those present and that the quantity is not characterized by cohesion but by dispersion (Nancy 2000 , p. 40). If one reads Nancy's concept from the perspective of social choreography (as with Hewitt), there arises the challenge of perceiving the choreographic movement as an open system rather than a closed one. The assembly is no longer a closed system, as it necessarily has porous boundaries that allow for 'just turning up' as well as 'departure' from the fabric of the collective. Choreographic formats that emerge in the context of protest should accordingly enable precisely this staging of collectivity; my thesis posits that the choreographic format of Circle Dancing does exactly this.

\section{Circle Dancing in the Political Context}

Circle Dancing as happenings within political movements in the context of assemblies were most evident during the occupation of public spacessuch as Occupy Wall Street (2011), the protests in Syntagma Square, Athens (2011), the aforementioned Gezi Park protests at Taksim Square in Istanbul (2013), and during the Arab Spring (2011). Jamshidi describes how in 'the face of brutality and repression from security forces, the festive atmosphere created by outbursts of dance and music has helped keep people on the streets' (Jamshidi 2014, p. 90f). The 'festive atmosphere' 
joyfully supports the efforts to maintain a presence in the square, a purposeful act used as a strategy to counter violent and extremely physically challenging situations, such as when tear gas is being used. Tsomou describes - with regard to the protests in Syntagma Square 2011, Athenshow dancing 'has become a sustainable strategy on the square' (Tsomou 2014 , p. 133) (translation by author). Tsomou, as with Uluğ Acar, understands that:

The community of the 'we', the '99\%' or the 'indignant' is not constituted by origin, group association or membership - its operative idiosyncrasy is to be found in the presence of the individual as well as in the practices in the squares. (Tsomou 2014, p. $116 \mathrm{f}$, translation by author)

Walton confirms this finding in his investigation of the carnivalesque nature of the Gezi Park protests ${ }^{6}$ at Taksim Square, Istanbul 2013:

Gezi was defined by the conglomeration of multiple political identities. What linked the protestors was not an identity, but a novel, emphatic practice of citizenship, a public performativity. (Walton 2015, p. 51)

Among other aspects, Walton goes into detail about the YouTube video Everyday I'm Capulling. ${ }^{7}$ In this video, which consists of a series of short moments and situations in Taksim Square, one can see groups of protesters Circle Dancing (balay çekmek). The festive character of the protest can clearly be witnessed. Walton quotes Bakhtin in his study, who describes the carnival as an exceptional social situation along with its potential for change (Bakhtin 1984, cited in Walton 2015, p. 51).

Accordingly, it is possible to speak-in the context of protest-of an atmospheric territory that is permanently defended by aesthetic strategies such as dancing, singing, choric speaking, music making and so on. Böhme describes the way in which atmosphere is generated as a type of power (Böhme 1993, p.125). Tsomou points out—on the occasion of the Circle Dancing at Syntagma Square in Athens, 2011-that dancing works as a strategy for preventing a place from being evacuated quickly:

The circle dancing at Syntagma Square had a double quality: On the one hand they emerged as a tactical response to conflicts with the police; and on the other hand they were not a planned strategy of confrontation, but rather were an end in and of themselves in the sense of experiencing shared happiness $[\ldots]$ [and] self-care, a self-oriented ritual of perseverance in order not to 
let the place be so easily cleared [...]. (Tsomou 2014, p. 134f, translation by author)

The citation suggests that by 'experiencing shared happiness', the creation of a certain atmosphere is inseparable from the question of power (or who is allowed to stay where?). Circle Dancing serves, above all, to define an atmospheric territory. The carnivalesque functions as an integrative element, which is able to gather different social and political identities. It incorporates a wide range of social and cultural practices.

\section{'If I Can't Dance, I Don't Want to Be Part of Your Revolution': Change and New Temporalities}

The practices that can be observed in different places are usually amassed from the experience of different types of protest. These can be seen in measures such as the installation of camps or tent sites; strong selforganization to meet existential needs, based on the development of a corresponding infrastructure; direct democratic meeting structures; the renunciation of hierarchical structures and the rejection of political representation; work with media and social networks; creative interaction with oppression; physical practices (such as yoga courses); and, among other things, performative formats such as collective dancing. Teune speaks about 'prefigurational politics [...] that anticipate the needs of the desired society by taking concrete action' (Teune 2012, p. 34, translation by author).

This 'experimental conduct' within the framework of prefigurational politics is a form of open and future-oriented action that enables the testing of new cultures and configurations of movement. The mobilization of bodies and 'communities in the making' (Kunst 2014, p. 18, translation by author) imbues a processual and transformative character that makes the movement open for change, conveying 'utopian moments'. This is also reflected in German formulations such as etwas bewegen ('to make change') or die Verbältnisse zum Tanzen bringen ('to make the circumstances dance'). According to Gormly, dancing seems particularly predestined to actually make change possible: 'Dance is a state of excitement in a system where change becomes possible, desirable, fluid and pleasurable' (Gormly 2012, p. 1). 
The theme of transition and change ('Time for change') ${ }^{8}$ is closely tied to a shifting temporality; it is not only about the experiences that the participants gain by investing time in the various protest practices mentioned above, but also about the construction of new temporalities via collective practices, and 'pertains to the dynamics that are ultimately decisive in determining the timbre of the present moment in time' (van Eikels 2013, p. 176, translation by author). Della Porta, who has dealt with events that characterize protests within social movements, speaks of 'eventful protests' in this context that enable processes through which collective experiences can be made. 'Eventful temporality' is characteristic of these 'protest events' (della Porta 2008, p. 3). 'Eventful temporality recognizes the power of events in history [...]' (Sewell 1992, p. 262, quoted in: della Porta 2008, p. 3).

Hardt and Negri, together with Aristotle, emphasize the importance of the movement between a before and after for phases of social transition and upheaval, by describing the transformation of the time horizon as an active process: 'In particular, the multitude takes hold of time and constructs new temporalities [...]' (Hardt and Negri 2000, p. 401). They further develop this idea into the following definition of time: 'Time might thus be defined as the immeasurability of the movement between a before and an after, an immanent process of constitution' (Hardt and Negri 2000, p. 402, author's emphasis).

Thus, the physical movement is that which is constitutive for the moment of the transition and, in the case of collective movement, becomes a 'performance of a reciprocal measurement and admeasurement of time' (van Eikels 2012, p. 170, translation by author). This admeasurement of time is executed in dance via synchronization through the duration of movement, which is organized chronologically by rhythm. Dance can thereby enable a new provisional 'timeline' to be practised and lived. 'Dance in its most potent form manages to momentarily "live" new orders' (O'Ros, quoted in: Gormly 2012, p. 1). Thus, the choreographic movement becomes an aspect of the aesthetic of change (Klien 2008, p. 2).

In the next chapter, I will show why the choreographic format of Circle Dancing is particularly suitable for staging a new social order. 


\section{Circle Dancing and the Round Dance as Choreographic Formats}

Circle Dancing is generally understood as a dance with a circular line-up of dancers, in which the dancers stand next to each other, hold hands or shoulders and face the middle of the circle.

As the penultimate geometric symbol, the circle stands for the universe, the globe, unity, harmony and the perfection of the world. Circle Dancing is one of the oldest anthropologically symbolic expressions of humanity, making possible a dialogue between interior and exterior worlds. Traditionally, dances have accompanied important rituals of transition, rituals in which the theme of change is present. Such transitional rituals are celebrated by the whole community as transformational ceremonies. The location for the ritual is the ceremonial 'village square', where a fire burns in the centre; there is singing, drumming and dancing. In dance rituals, psychic energies materialize. With their bodies, dancers express communicative concerns that go beyond themselves.

In the present day, Circle Dancing is often practised in the context of folk dance. The folk dance, as a concept in Germany, is saddled with negative connotations due to its 'cultural-political instrumentalization in National Socialism and the GDR' (Evert 2014, p. 45, translation by author), as it served as a space for compositional, ideological and functional attribution. For, of course, in the context of 'folk dance' the question always arises, "Who are "the folk"?' The pleasure of dancing, in particular, served as a 'gateway for assimilation by political ideologies from left and right' (Evert 2014, p. 40) (translation by author). Hanna Walsdorf proposes the following ahistorical definition for the concept of folk dancing:

Folk dancing is arranged and socially produced, experienced and mediated.

It is a sociable dance that can be learned by everyone, which constitutes, confirms and represents a community; however, the moment it is placed on a stage it is transformed from a social event to the demonstration of expository spectacle. (Walsdorf 2010 , p. 2, translation by author)

Dance as 'exposition' joins the political fray when it is performed on the stage of public space. In the activist context, it is important that this formation of community does not take place via an idea, but rather through physical practice. This makes it an interesting method within the scope of 
the recent occupations of public space, as these gatherings are composed of extremely heterogeneous groups. The dances contribute,

$[\ldots]$ to the formation of community. [...] When people from different walks of life dance together, they put the differences between them into the background. Their dance movements only succeed when they relate to each other and cooperate. [...] In the scope of this deferment of differences they create a feeling of togetherness in rhythmic movement. (Wulf 2010, p. 38f, translation by author)

Circle Dancing and the Round Dance are easily accessible to ordinary people as a choreographic format. One does not need previous knowledge, special dance skills or a professional dance education; the dance steps are easy to learn through clear instruction-often musically supportedand are repeated in cycles, which encourages people to join in. It succeeds through participation. One does not need a dance partner; partners are interchangeable, allowing a fluid stream of dancers to join in. The movements are an open system, an assembly with porous membranes allowing for both a 'showing up to' and a 'departing from' the movement (see section "Gathering in the Movement"). In the case of a closed circle, the newcomer simply picks a spot to break the circle, takes the hands of the dancers on either side and fills the space between with their body. When a dancer leaves the circle, the circle is simply closed once more with the joining of hands.

Unclosed circles can often be observed, in which case there are openings and a round formation is extant. These openings make it even easier to get started. 'The round open structure seems particularly suitable as an entrance and a foundation for dancing together [...]' (Evert 2014, p. 47, translation by author) In the case of Kurdish Round Dances, usually an experienced dancer initially 'leads' the dance and is visually marked by a swath of fabric held in the free hand. The cloth is exchanged when a new leader takes over. Despite these small differences, Circle Dancing is, by its nature, non-hierarchical-there is no 'starting-point'-every dancer is equally important.

The differences within the movements that result from the varying levels of experience of the dancers, and contrasting body shapes and personal movement characteristics are decisive aspects of the choreographic format of Circle Dancing. 
Another important aspect is that the circle formation offers the greatest possible visibility of the dancers, both as members of the circle dynamic and from the perspective of the audience. Whereas each of the dancers can see all of the other dancers of the group at any time, those outside of the circle can see the dance as a whole and watch the individuals pass by as the circle rotates.

There is no central perspective from which one could best see the dance. There are only multiple, ever-changing views to the situation. This corresponds to a multiperspectivity of content which, in the context of protest, generally (and by definition) stands in opposition to the prevailing state ideology.

Another aspect of the non-hierarchical character of Circle Dancing is that each dancer leads and is led by their neighbours at the same time. Lepecki calls this 'a-personal leadingfollowing' (Lepecki 2013, p. 37). This leading/following in Circle Dancing corresponds to self-organizing structures of social movements. In the context of larger assembly, the individual assumes personal responsibility, while also transferring a great deal of responsibility to the collective. This requires that the individual trusts the group and shows flexibility regarding their dynamic position within it. 'Feeling valued' and 'being seen' are important factors of emotional wellbeing in large groups, which is why the maintenance of visibility for each Circle Dancing member is of positive psychosocial merit and not merely a side effect.

Another very important effect of Circle Dancing is that it facilitates the synchronization of a large group. Synchronization is essential for a functioning collective, and the choreographic format of Circle Dancing can serve to establish a very specific form of collectivity, namely that of the collective movement that is needed by the body's response/ability. This is a description of the practice of 'attuning', which Prades describes as a way 'to harmonise'. ${ }^{10}$ It points to the importance of finding a common rhythm for a movement or action. Decisive here is that the process of synchronization $^{11}$ never leads to perfect uniformity - it is always in the making; it is transient, volatile and reversible, even if it appears to be stable for a certain time. That means that one has to 'attune' again and again.

A precondition for synchronization is a great attention ('body awareness') for both one's own body and those of the other(s). The dance creates a state of alertness and can thus also be seen as a form of body meditation. The physical disposition is described by Prades as a state of fluid attention, in which all the senses are adjusted to the reception of the 
environment: 'Our senses must be receptive and our body absolutely present' (Prades 2013, p. 214). This state of physical attention emerged as early as 1965, in one of the classics of activist practice. In the handbook, Manual for Direct Action: Strategy and Tactics for Civil Rights and All Other Nonviolent Protest Movements, Oppenheimer and Lakey recommend 'ideal body awareness when engaging in protest' (Oppenheimer and Lakey 1965, quoted in Harrington 2016, p. 7). These physically challenging situations require mindfulness, which is about the active discovery of possibilities of movement.

Another important effect of the circle is the phenomenon of rhythm, which helps overcome exhaustion. Within the group, the common body experience and the 'vibe' are experienced as self-empowerment. McNeill describes the mechanism of rhythm structures and how the visceral phenomenon of 'muscular bonding' leads to 'emotional bonding' between the jointly moving people (McNeill 1997, p. 2f). This type of community formation by 'the euphoric fellow feeling' (joyful proximity to a neighbour) is of great importance for social movements, as it builds trust. The physical aptitude of the dancers thereby leads to an intuitive, affective, empathic pre-linguistic understanding of moving jointly in rhythm.

\section{Circle Dancing as Staged Social Order}

And so, in the most ideal instances, an alliance begins to enact the social order it seeks to bring about by establishing its own modes of sociability. (Butler 2015, p. 84)

Based on the considerations from the previous chapters, the following can be said:

Circle Dancing orchestrates equality, visibility, multivarious positions in space and continuous changes of perspective. The person is understood as a relational and social being, moving in a collective context to which one can 'show up' and from which one can 'depart'. Thus, the community is staged as an open structure. Furthermore, dancing in public space is a very fundamental way of staging of freedom. 'I will dance despite everything' 12 was the title of a flashmob performance in Tunis, initiated in December 2012 by Art Solution working with a Tunisian group, Service de l'Underground, who promoted dancing by 'citizen dancers' in public spaces as resistance against extremists trying to limit the freedom of the body in public. Butler describes how the human body at assemblies 'is on the line, exhibiting its value and its 
freedom' (Butler 2015, p. 17). This is especially true for the dancing body. It stands for freedom; a body in motion is difficult to control. In the case of the aforementioned flashmob, the body is liberated, at least temporarily free.

The strength of a group in Circle Dancing or Round Dance is performed offensively and concentrated inwards. This demonstration of strength is also underlined by the fact that, even in violent demonstration situations, the dancers can 'afford' to turn their back on the oppressive forces. Thus, the body is exhibited in its vulnerability from which it gains its immanent strength, as Butler convincingly shows. Circle Dancing marks a specific place in the public realm as its own space ('our place') and thereby temporarily claims atmospheric territory. Circle Dancing instantiates an alliance that is based on equality in a situation that is usually characterized by extreme imbalance of power: 'They are asserting equality in the midst of inequality' (Butler 2013). This equality is founded upon closeness and connectedness, which is made clear by the touch of the dancers on each other's arms and/or shoulders. The German formulation Schulterschluss demonstrieren (demonstrate shoulder to shoulder) displays implicit knowledge about the real and symbolic power of this bodily gesture. People sit 'shoulder to shoulder' for a common cause at a difficult time; the term Schulterschluss (closing of the ranks) describes the merger of several people into an alliance. The image of people gripping each other's shoulders stands for solidarity and fraternity. In addition to strong symbolic content, this kind of touch holds great importance in the field of affection.

\section{Affection and Turmoil: Contact in Circle Dancing}

Touching others physically and being touched is essential for people to maintain connection with the world. As Böhler notes, there is a direct connection between touch and reality: ' $(. .$.$) this is the very meaning of touch-$ ing: it gives us a sense of reality (...) it actually gives a feeling of something that in fact exists outside oneself' (Böhler 2011, pp. 39-40). He emphasizes that this is an act of extroversion in relation to the activity of touching (Böhler 2011, p. 41).

The moment of leaving one's personal universe- a factor in the active contact-also has an unmistakable influence on the degree of the individual body's ability to experience affection. Thus, Mittmannsgruber and Schäfer define the contact as follows: 'The touch is the body's "moving 
beyond". Its stretching, the spreading and widening of its aptitude' (Mittmannsgruber and Schäfer 2013, p. 197, translation by author).

If, in this sense, the dancing body is imagined in a protest situation, the importance of physical contact for this temporary community becomes clear; the bodies recall their power of affecting others through the touch inherent in the dance. The success or failure of social movements depends on the way these powers of the protesters are realized and used in order to affect their environment. Mittmannsgruber and Schäfer describe the intrinsic power in the body as resulting from a mobile field of forces in this situation: 'Bodies are fields of force $[. .$.$] they are relationship braids [\ldots]$. And every single body is to be regarded as power, namely, to affect and be affected by power. To touch and be touched' (Mittmannsgruber and Schäfer 2013, p. 196, translation by author).

The experience of being a member within the dancing group, part of the force field and realizing its energy, is felt in the group as a moment of self-empowerment. It is both a sense of self-efficacy and a very concrete assessment of possibilities for action. Slaby, who is concerned with the connection between affective states and the awareness of possibilities for action and agency, emphasizes the importance of affective states as an 'interface' for the capacity of acting of a group (Slaby 2012, p. 152). The mutual awareness of possibilities for action-'we can' or 'we cannot'-is important as an ongoing process of self-assurance and positioning for groups that want to remain active in the political space. Flam describes the form of emotional work undertaken by social movements and how they re-socialize their members by working on emotions: '[...] social movements re-define dominant feeling rules' (Flam 2005, p. 19). She continues by describing ways in which cultural elements, such as various forms of rhythm and loud sounds, serve as fear-management devices (Flam 2005, p. 29). The choreographic formats of Circle Dancing and the Round Dance can be regarded as affective work in this context - on the one hand, to collectively manage negative emotions such as anxiety and, on the other hand, to maintain agency and a capacity to act. The mindsets of the dancers are changed by experiencing themselves as human beings in contact and connection with other people (Slaby 2012, p. 154).

To be active in the political arena, it is important to feel agency and the world as a space of specific (action) opportunities. This is the reason why a classical form of protest, such as the demonstration, still makes sense in today's media-democracy; shared movement in public space is being 'in motion' in a double sense. The state of being 'in motion' is experienced in 
a very special way when dancing in public space: The affective state-arising through touch and dancing together-can lead to a euphoric, prerevolutionary state. In his essay Rühren, Berübren, Aufrubr ('Stirring, Stirring Up, Uprising'), Nancy describes the connection between touch and political uproar from an analysis of the word rubr-a common wordstem in the German language:

Rübren, Berühren, Aufrubr. German makes it possible to gather three notions in the semantic family of $r u b r$, which we can match in French with le bouger, l'agiter, le toucher and le soulèvement [and in English: 'moving', 'agitating', 'touching' and 'uproar']; and each of these terms can be understood with its own array of possible values. 'Moving' and 'agitating' convey some physical as well as moral senses, as do 'touching' and 'uprising'. The latter term, for its part, gives its moral value a socio-political orientation. (Nancy 2011, p. 8 )

The word 'family' refers to the field of movement, a movement which is directly connected with the range of affections, the e-motions. Nancy points out that one must move in order to touch: 'Now, one can only understand the identity of touching and touched as the identity of a movement, a motion and an emotion' (Nancy 2011, p. 12).

Touch - and being touched - are the point of convergence of the political movement; the real physical, choreographic movement, and the associated inner movement and affectation.

Circle Dancing and the Round Dance are aspects of a physical practice within which the gathering bodies, in their performance and vulnerability, open up a field of meaning in the public where the political takes place in the relational 'in-between-ness' of the moving bodies. Nancy described the socio-political turmoil in which the dancing body is located, essentially dealing with overcoming body boundaries: 'The body rises up, as the German word Aufruhr suggests, designating, as I pointed out, a sociopolitical uprising. [...] A body rises up against its own enclosure' (Nancy 2011 , p. 15). Thus the isolation of the individual is also broken in Circle Dancing and the Round Dance.

In summary, it can be said that the interpersonal contact and affection extant in the choreographic formats of Circle Dancing and the Round Dance (within the framework of the social convention of dancing) demarcate an atmospheric territory. Through this, the world can be concretely experienced as a space of specific (action) possibilities. This realm is a space 
of multiple movements: the political, the choreographic and the emotional. These overlapping experiences of movement and 'emotional bonding' that it triggers lead to the formation of a resilient community, which is the prerequisite for any kind of political action. Moreover, in the choreographic format of Circle Dancing and the Round Dance, a form of future-oriented sociability is temporarily established, staged and practised as a matrix of collective action. When these choreographic formats appear in the context of political meetings, protests and occupations, they become part of a prefigurative policy. The body's abilities to touch and be touched, along with its 'response/ability', are at the centre of this practice of collective movement that simultaneously exercises and celebrates sharing itself in a gathering in (the) movement.

\section{Notes}

1. 'After all, there is an indexical force of the body (...): it is this body, and these bodies, that require employment, shelter, health care, and food, as well as a sense of a future (...)' (Butler 2015, p. 9).

2. See the socio-psychological investigation about the protests in 2013 in Istanbul by Özden M. Uluğ and Yasemin G. Acar (2015) 'We are more than Alliances between Groups' in Everywhere Taksim. Sowing the Seeds for a New Turkey.

3. See the collective concept of Kai van Eikel's in Kai van Eikels (2013) Die Kunst des Kollktiven: Performance zwischen Theater, Politik und Sozio-Ökonomie.

4. Milohnic (2013) Choreographies of Resistance/Partisan Choreography, Walking Theory, 21 Social Choreography, 15-20.

5. Klein, G. (2013) 'Collective Bodies of Protest: Social Choreographies in Urban Performance Art and Social Movements', Walking Theory, 21 Social Choreography, 29-33, http://www.tkh-generator.net/portfolio/ tkh-21-social-choreography/, date accessed 23 February 2018.

6. See Walton, Jeremy F. (2015) “'Everyday I'm Çapulling!” Global Flows and Local Frictions of Gezi' in Everywhere Taksim. Sowing the Seeds for a New Turkey.

7. The video is available at https://www.youtube.com/watch?v=QV0NT UY0Zls, date accessed 19 September 2017.

8. Halliday identifies the following four meanings that are important to the theory of revolution: (1) Commitment of the population, (2) Progress, (3) Beginning of a new age, (4) Total change. See, Fred Halliday (1999) Revolution and World Politics. 
9. For in-depth discussion of this problem, please refer to Hanna Walsdorf (2010) Bewegte Propaganda. Politische Instrumentalisierung von Volkstanz in den deutschen Diktaturen.

10. Prades, Pepón (2013) 'Ideas that are born from the body. Brainstorming and improvisation' in A. Böhler; Ch. Herzog; A. Pechriggl, (eds) Korporale Performanz. Zur bedeutungsgenerierenden Dimension des Leibes.

11. On the topic of synchronization, see Kai van Eikels (2012) 'From "Archein" to "Prattein" - Suggestions for an Un-creative Collectivity' in E. Besteri; E. Guidi; E. Ricci (eds) Rehearsing Collectivity. Choreography Beyond Dance.

12. Video documentation of 'I will dance despite everything', http://www. freearabs.com/index.php/art/79-video-gallery/304-jb-span-tunisia-jbspan-dancing-in-the-street, date accessed 19 September 2017.

\section{REFERENCES}

Berger, C., and S. Schmidt. 2009. Körperwissen und Bewegunsglogik. In Ordnung in Bewegung. Choreografien des Sozialen. Körper in Sport, Tanz, Arbeit und Bildung, ed. K. Brümmer, R. Kodalle, and T. Pille. Bielefeld: transcript.

Böhler, A. 2011. On Touching. In Tanzquartier Wien, Scores $\mathrm{N}^{\circ} 1$ touché. http://www.tqw.at/sites/default/files/Scores_1_Kern_Web_FINAL.pdf. Accessed 9 Oct 2017.

- 2014. 'Do We Know What a Body Can Do?' \#1 Interview with Arno Böhler and Erin Manning. In Wissen wir, was ein Körper vermag? Rhizomatische Körper in Religion, Kunst, Philosophie, ed. A. Böhler, K. Kruschkova, and V. Susanne. Bielefeld: transcript.

Böhme, G. 1993. Atmosphere as the Fundamental Concept of a New Aesthetics. Thesis Eleven 36: 113-26. Sage. http://journals.sagepub.com/doi/ pdf/10.1177/072551369303600107. Accessed 9 Oct 2017.

Butler, J. 2011. Bodies in Alliance and the Politics of the Street (2017a). http:// www.eipcp.net/transversal/1011/butler/en. Accessed 18 Jan 2017.

- 2013. Freedom of Assembly or Who Are the People. Given as a Lecture at Boğaziçi University, Istanbul (2017a). https://www.youtube.com/ watch?v=Yd-7iT2JtXk. Accessed 9 Oct 2017.

- 2015. Notes Toward a Performative Theory of Assembly. London: Harvard University Press; eBook.

della Porta, D. 2008. Eventful Protest, Global Conflicts (2017a). https://www. bc.edu/content/dam/files/schools/cas_sites/sociology/pdf/ EventfulProtest.pdf. Accessed 9 Oct 2017.

Elden, S. 2011. Die Entstehung des Territoriums (2017a). http://www.geographie.nat.uni-erlangen.de/wp-content/uploads/EBK_l.pdf. Accessed 18 Jan 2017. 
Elias, N. 1978. What Is Sociology? Trans. Stephen Mennell, and Grace Morrissey. London/New York: Hutchinson and Columbia University Press.

Evert, K. 2014. Gemeinsam Tanzen. In Versammlung und Teilhabe, ed. R.V. Burri, K. Evert, S. Peters, E. Pilkington, and G. Ziemer. Bielefeld: transcript.

Flam, H. 2005. Emotions' Map. A Research Agenda. In Emotions and Social Movements, ed. H. Flam and D. King. Oxon/New York: Routledge.

Gormly, J. 2012. What Is Social Choreography? http://www.choreograph.net. Accessed 24 Nov 2014.

Halliday, F. 1999. Revolution and World Politics: The Rise and Fall of the Sixth Great Power. Durham: Duke University Press.

Hardt, M., and A. Negri. 2000. Empire. Cambridge/London: Harvard University Press.

Harrington, H. 2016. Site-Specific Protest Dance: Women in the Middle East. http://dancercitizen.org/issue-2/heather-harrington/. Accessed 9 Oct 2017.

Hewitt, A. 2005. Social Choreography: Ideology as Performance in Dance and Everyday Movement. Durham/London: Duke University Press.

Hölscher, S., and G. Siegmund, eds. 2013. Dance, Politics \& Co-immunity. Vol. 1. Zurich/Berlin: diaphanes.

Jamshidi, M. 2014. The Future of the Arab Spring: Civic Entrepreneurship in Politics, Art and Technology Start Ups. Oxford: Butterworth-Heinemann.

Kaltenbrunner, T. 2004. Contact Improvisation. Moving - Dancing - Interaction. Trans. Nick Procyk. Oxford: Meyer \& Meyer Sport.

Klein, G. 2013. Collective Bodies of Protest: Social Choreographies in Urban Performance Art and Social Movements. Walking Theory 21 Social Choreography: 29-33. http://www.tkh-generator.net/portfolio/tkh-21-social-choreography/. Accessed 23 Feb 2018.

Klien, M. 2008. Choreography as an Aesthetics of Change (Dissertation - Edinburgh College of Art, Scotland) (2017a). https://www.academia.edu/3809926/ CHOREOGRAPHY_AS_AN_AESTHETICS_OF_CHANGE. Accessed 9 Oct 2017.

Kunst, B. 2014. Die partizipative Politik des Tanzes. In Kampnagel; Internationales Theaterinstitut Katalog Tanzplattform Deutschland. Berlin: Kampnagel Internationale Kulturfabrik $\mathrm{GmbH}$ und Internationales Theaterinstitut Zentrum Deutschland.

Lepecki, A. 2013. 'From Partaking to Initiating: Leadfollowing as Dance's (a-Personal) Political Singularity. In Dance, Politics \& Co-Immunity, ed. S. Hölscher and G. Siegmund, vol. 1. Zurich/Berlin: diaphanes.

Lorey, S. 2014. Performative Sammlungen. Sammeln und Ordnen als künstlerische Verfahrensweise - eine Begriffsbestimmung. In Versammlung und Teilhabe, ed. R.V. Burri, K. Evert, S. Peters, E. Pilkington, and G. Ziemer. Bielefeld: transcript.

McNeill, W.H. 1997. Keeping Together in Time: Dance and Drill in Human History. Cambridge, MA: Harvard University Press. 
Milohnic, A. 2013. Choreographies of Resistance. Walking Theory 21 Social Choreography: 15-20.

Mittmansgruber, M., and E. Schäfer. 2013. Immer wieder - die Körper! In Korporale Performanz. Zur bedeutungsgenerierenden Dimension des Leibes, ed. A. Böhler, C. Herzog, and A. Pechriggl. Bielefeld: transcript.

Nancy, J.-L. 2000. Being Singular Plural. Trans. Robert D. Richardson, and Anne E. O'Byrne. Stanford: Stanford University Press.

- 2011. Rühren, Berühren, Aufruhr (Stirring, Stirring up, Uprising). Trans. Christine Irizarry. In Tanzquartier Wien, Scores $\mathrm{N}^{\circ} 1$ touché. http://www.tqw. at/sites/default/files/Scores_1_Kern_Web_FINAL.pdf. Accessed 9 Oct 2017.

Oppenheimer, M., and G. Lakey. 1965. Manual for Direct Action: Strategy and Tactics for Civil Rights and All Other Nonviolent Protest Movements. New York: Quadrangle Books.

Prades, P. 2013. Ideas that Are Born from the Body. Brainstorming and Improvisation in A. Böhler; Ch. Herzog; A. Pechriggl, Korporale Performanz. Zur bedeutungsgenerierenden Dimension des Leibes (Bielefeld: transcript).

Slaby, J. 2012. Affective Self-Construal and the Sense of Ability. In Emotion Review 4/2. http://janslaby.com/downloads/slaby2012_affectiveselfconstrual_ emorev.pdf. Accessed 9 Oct 2017.

Teune, S. 2012. Das produktive Moment der Krise. Platzbesetzungen als Laboratorien der Demokratie. WZB Mitteilungen Heft 137: 32-34.

Tsomou, M. 2014. Der besetzte Syntagma-Platz 2011: Körper und Performativität im politischen Alphabet der >Empörten<. In Versammlung und Teilhabe, ed. R.V. Burri, K. Evert, S. Peters, E. Pilkington, and G. Ziemer. Bielefeld: transcript.

Uluğ, Ö.M., and Y.G. Acar. 2015. "We Are More Than Alliances Between Groups". A Social Psychological Perspective on the Gezi Park Protesters and Negotiating Levels of Identity. In Everywhere Taksim. Sewing the Seeds for a New Turkey, ed. I. David and K.F. Toktamis. Amsterdam: Amsterdam University Press.

van Eikels, K. 2012. From “Archein” to "Prattein” - Suggestions for an Un-creative Collectivity. In Rehearsing Collectivity. Choreography Beyond Dance, ed. E. Besteri, E. Guidi, and E. Ricci. Berlin: Argobooks.

- 2013. Die Kunst des Kollektiven: Performance zwischen Theater, Politik und Sozio-Ökonomie. Munich/Paderborn: Wilhelm Fink Verlag.

Walsdorf, H. 2010. Bewegte Propaganda. Politische Instrumentalisierung von Volkstanz in den deutschen Diktaturen. Würzburg: Königshausen \& Neumann. Walton, J.F. 2015. "Everyday I'm Çapulling!” Global Flows and Local Frictions of Gezi. In Everywhere Taksim. Sewing the Seeds for a New Turkey, ed. I. David and K.F. Toktamis. Amsterdam: Amsterdam University Press.

Wulf, C. 2010. Anthropologische Dimensionen des Tanzes. In Konzepte der Tanzkultur. Wissen und Wege der Tanzforschung, ed. M. Bischof and C. Rosiny. Bielefeld: transcript. 
Open Access This chapter is licensed under the terms of the Creative Commons Attribution 4.0 International License (http://creativecommons.org/licenses/ by $/ 4.0 /$ ), which permits use, sharing, adaptation, distribution and reproduction in any medium or format, as long as you give appropriate credit to the original author(s) and the source, provide a link to the Creative Commons licence and indicate if changes were made.

The images or other third party material in this chapter are included in the chapter's Creative Commons licence, unless indicated otherwise in a credit line to the material. If material is not included in the chapter's Creative Commons licence and your intended use is not permitted by statutory regulation or exceeds the permitted use, you will need to obtain permission directly from the copyright holder.

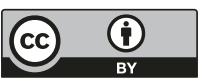

